\title{
MEMBANGKITKAN KEPEDULIAN LINGKUNGAN MELALUI PEMBERDAYAAN MASYARAKAT GUNA MENJAMIN KEBERLANJUTAN FUNGSI DAS CITARUM
}

\author{
Rita Retnowati ${ }^{1}$, Rita Istiana ${ }^{2}$ \\ ${ }^{1}$ Dosen Prodi Managemen Lingkungan, Pascasarjana, Universitas Pakuan \\ ${ }^{2}$ Dosen Prodi Pendidikan Biologi, FKIP, Universitas Pakuan \\ Email: rita_istiana@unpak.ac.id
}

\begin{abstract}
Abstrak
Rendahnya sikap peduli lingkungan masyarakat di sekitar DAS Citarum untuk turut melestarikan DAS merupakan salah satu faktor penyebab tercemarnya sungai Citarum. Kegiatan pengabdian kepada masyarakat ini bertujuan untuk membangkitkan kepedulian lingkungan masyarakat di sekitar DAS Citarum sehingga dapat menjamin keberlanjutan fungsi DAS Citarum. Kegiatan pemberdayaan masyarakat ini dilakukan dengan metode diskusi dan demonstrasi yang melibatkan masyarakat, siswa, karyawan dan aparat TNI. Kegiatan dilakukan pada tanggal 15-16 Desember 2018 bertempat di Desa Cisalada dan Desa. Parakanlima Kec. Jatiluhur Kab. Purwakarta Jawa Barat. Persentase skor sikap kepedulian lingkungan sebesar 78,48\% pada karyawan; 84,9\% pada siswa dan 75,3\% pada masyarakat yang diukur dengan menggunakan instrument kuisioner tentang sikap peduli lingkungan satu bulan setelah selesai diberikan penyuluhan. Dari hasil angket tersebut memberikan gambaran bahwa kegiatan ini efektif dalam membangkitkan kepedulian masyarakat disekitar DAS Citarum.
\end{abstract}

Kata kunci: Sikap peduli lingkungan, sungai citarum, pemberdayaan masyarakat

\section{PENDAHULUAN}

Manusia dalam menjaga hidupnya sangat tergantung pada keberadaan air yang bersih dan sehat (Lawrence dan Meigh, 2003). Air bahkan menjadi komponen yang sangat penting dalam kehidupan semua makhluk. Sumber air yang digunakan berasal dari berbagai sumber, antara lain berasal dari sumber air tanah, air yang di tampung dalam waduk bahkan sebagian besar menggantungkan hidup pada air yang berasal dari sungai. Masyarakat Indonesia sebagian besar menggunakan air dari aliran sungai untuk mendukung kelanjutan hidupnya. Mulai dari untuk mandi bahkan memasak makanannya. Akan tetapi yang mengkawatirkan adalah kondisi air sungai tidak sebersih dan sesehat yang semestinya. Sebagian besar sungai yang ada dalam kondisi tercemar seiring makin bertambahnya jumlah penduduk dan 
DIFUSI

Volume 2, No.2 Juli 2019

era industrialisasi yang berkembang sangat cepat (Liang dan Yang, 2018).

Pada saat ini, yang menjadi sorotan utama adalah Daerah Aliran Sungai Citarum di Jawa Barat. Telah banyak peneliti yang meneliti kualitas Air sungai Citarum. Salah satu peneliti membagi DAS Citarum menjadi 3 (tiga) zona yaitu Citarum Hulu, Citarum Tengah dan Citarum Hilir. Secara umum menjelaskan bahwa pencemaran akibat limbah permukiman, industry, pertanian. Secara umum dapat disimpulkan bahwa pencemaran yang terjadi karena disebabkan oleh perilaku oleh manusia. Limbah pemukiman, akan menjadi pencemar DAS Citarum apabila semua masyarakat yang tinggal disepanjang DAS tidak memiliki kepedulian untuk turut melestarikan DAS, dengan mereka membuang limbah pemukiman di saluran DAS maka limbah pemukiman akan terakumulasi menjadi satu pencemaran yang sangat besar, mengingat berapa banyaknya manusia dan perkampungan yang berada di sepanjang bantaran sungai Citarum (Wihardjo, Hartati, Nurani, dan Sujarwanta, 2017).

Perilaku pelaku industri yang tidak taat aturan pun menjadi sumber polutan yang signifikan bagi Citarum. Air limbah industri yang seharusnya di olah terlebih dahulu (sesuai ketentuan), apabila di buang langsung ke sungai akan mengakibatkan tercemarnya sungai. Kejadian ini terjadi karena perilaku manusia pengelola industri yang mengabaikan kelestarian lingkungan, demi mengejar keuntungan finansial (mengutamakan faktor ekonomi dengan mengabaikan faktor kepentingan lingkungan). Demikian pula dengan penyebab pence- maran yang berasal dari sektor pertanian. Penggunaan pupuk kimia yang berlebih, pakan ikan yang berlebih dan terbawa ke aliran sungai, mengakibatkan tercemarnya DAS Citarum. Menurut Maulani dan Sumiarsa (2013) permasalahan Citarum sudah dimulai dari bagian hulu yang disebabkan karena berbagai ktivitas dan kurang terkendalinya limbah yang dibuang ke sungai, hai ini berdampak pada suplai air ba$\mathrm{ku} /$ bersih bagi penduduk. Berdasarkan penilaian Water Proverty Index (WPI) beberapa daerah di kabupaten Bandung mengalami kondisi kemiskinan air dengan nilai WPI di bawah 50 (Lawrence dan Meigh, 2003). Daerah-daerah yang diteliti berada di hulu sungai Citarum.

Memperhatikan penyebab pencemaran DAS Citarum yang berasal dari perilaku manusia tersebut, maka mahasiswa Program Studi Manajemen Lingkungan Pasca Sarjana Universitas Pakuan, tergerak untuk mengadakan kegiatan dalam rangka membantu mengurangi penyebab pencemaran DAS Citarum. Kegiatan tersebut di kemas dalam sebuah kegiatan Pengabdian Kepada Masyarakat (PKM). Menurut Wahyuningsih dan Pratama (2018) pemberdayaan masyarakat dalam kelestarian lingkungan amatlah penting. Masyarakat menjadi kunci utama dalam menjaga, melestarikan dan berkolaborasi dengan pemerintah dalam menjalankan program-program pelestarian alam. Masyarakat juga menjadi mitra pemerintah dalam memonitoring perubahan-perubahan yang terjadi pada lingkungan.

Sungai menjadi bagian kehidupan masyarakat Indonesia yang sangat penting 
DIFUSI

Volume 2, No.2 Juli 2019

dari dulu hingga saat ini. Daratan di sekitar sungai menjadi penyangga penting dalam menjaga fungsi sungai untuk menampung, menyimpan, dan mengalirkan air yang berasal curah hujan serta sumber lainnya sehingga bermuara di laut, danau, atau waduk. Wilayah penyangga inilah yang disebut Daerah Aliran Sungai (DAS).

Saat ini, padatnya perumahan penduduk menjadi pemandangan yang lumrah di daerah aliran sungai. Hal ini diperburuk pula dengan pola hidup masyarakat yang tidak menjaga lingkungan sehingga menyebabkan kerusakan di daerah aliran sungai semakin parah. Kebiasaan membuang sampah di aliran sungai, penggundulan hutan untuk pembangunan permukiman, alih fungsi hutan menjadi lahan perkebunan dan pertanian, menjadi faktor yang menyebabkan kerusakan DAS.

Buruknya ekosistem DAS saat ini menjadi salah satu isu nasional, terutama setelah Sungai Citarum dinobatkan sebagai salah satu sungai tercemar di dunia. Kerusakan DAS mengakibatkan dampak besar dan merugikan banyak pihak. Banjir, longsor, erosi, dan berbagai bencana lainnya, menimbulkan kerugian besar yang dirasakan bukan hanya oleh masyarakat di sekitar DAS. Oleh sebab itu, pengelolaan DAS menjadi satu bagian penting dalam upaya pengendalian dan pengelolaan sumberdaya alam serta harus melibatkan berbagai pihak, mulai dari tingkat desa hingga nasional. Dari beberapa hasil pemberdayaan pada masyarakat sebelumnya menunjukkan bahwa adanya pendekatan kemasyarakatan dalam meningkatkan kesadaran terhadap lingkungan khususnya kepedu- lian terhadap DAS memiliki pengaruh yang baik dalam menjaga kelestarian DAS. Berdasarkan penelitian Mikro, Dan, Awang, Faida, dan Maryudi (2016) pemberdayaan masyarakat dalam mengelola DAS dapat berhasil apabila peran penyuluh terus ditingkatkan, tidak hanya dengan teknologi terbaru tetapi juga teknik komunikasi dan membangun kelompok yang produktif.

\section{METODE}

Pemberdayaan masyarakat dilakukan melalui penyuluhan kepada masarakat disekitar DAS Citarum, siswa sekolah di Madrasah Aliyah Kartaraharja desa Cisalada, dan juga karyawan pabrik PT. Berkah Alzico Antalatika Desa Cisalada dengan metode demonstarsi dan diskusi. Kegiatan ini juga didukung oleh Danramil, BPDAS, pemerintah desa, kelompok mahasiswa Pascasarjana Prodi Manajemen Lingkungan, Universitas Pakuan.

Alasan pemilihan objek penelitian siswa sekolah, masyarakat dan karyawan pabrik di sekitar DAS Citarum karena ketiga objek tersebut memiliki peran strategis dalam menjaga kelestarian DAS Citarum. Siswa sekolah dipilih bertujuan untuk menanamkan sedini mungkin kesadaran akan pentingnya kelestarian DAS, sedangkan masyarakat dan karyawan pabrik karena limbah rumah tangga dan pabrik di sekitar DAS Citarum memiliki andil besar dalam mencemarkan DAS Citarum. Dengan adanya pemahaman yang baik tentang masalah lingkungan dan dampak panjangnya bagi kehidupan diharapkan akan tertanam 
DIFUSI

Volume 2, No.2 Juli 2019

kepedulian dalam menjaga DAS Citarum.

Waktu dan tempat pelaksanaan kegiatan pengabdian Kepada Masyarakat adalah hari Sabtu s.d. Minggu, tanggal 15 s.d. 16 Desember 2018 bertempat di Desa Cisalada dan Desa. Parakanlima Kec. Jatiluhur Kab. Purwakarta Jawa Barat. Bahan yang digunakan dalam kegiatan pengabdian kepada masyarakat ini diantaranya alat pendeteksi pencemaran air, alat penjernih air sederhana, buku panduan pendeteksi pencemaran air, video tentang DAS Citarum, $\mathrm{pH}$ meter, thermometer, stop watch. Sikap peduli lingkungan diukur menggunakan instrument dalam bentuk kuisioner yang divalidasi oleh judgment ahli. Analisis data dilakukan secara deskriptif analisis.

\section{HASIL DAN PEMBAHASAN}

Pengabdian Kepada Masyarakat dilaksanakan dalam bentuk kegiatan sebagai berikut:

\section{Pemberdayaan masyarakat seki- tar DAS Citarum}

Kegiatan penyuluhan terhadap masyarakat dilakukan di kantor aula desa Cisalada, kecamatan Jatiluhur pada hari minggu 15 Desember 2018. Kegiatan dimulai pada pukul 13.00 WIB dengan pembuka oleh Sekretaris desa Cisalada dan dilanjutkan dengan penyuluhan dari nara sumber dari Dosen prodi Managemen Lingkungan, Pascasarjana, Universitas Pakuan. Kegiatan selesai pada pukul 16.30 WIB. Jumlah masyarakat yang terlibat dalam peyuluhan ini sebanyak 26 orang yang sebagian besar terdiri dari kepala rumah tangga.
Pada awal materi, peserta terlihat masih bingung, namun setelah pemutaran video tentang DAS Citarum serta beberapa alat peraga lainnya, peserta terlihat aktif dan memahami apa yang disampaikan oleh pemateri.

Materi pengabdian masyarakat berkaitan dengan materi pelestarian DAS, pengukuran kualitas air secara biologis dan kimia serta praktek penjernihan air. Penyampaian materi dilakukan dengan bahasa lokal sunda untuk memudahkan penerimaan peserta. Diakhir kegiatan dilanjutkan dengan kegiatan pengisian angket oleh para peserta. Selama penyampaian materi peserta diberi kesempatan untuk bertanya, mencoba dan mengamati hasil percobaan.

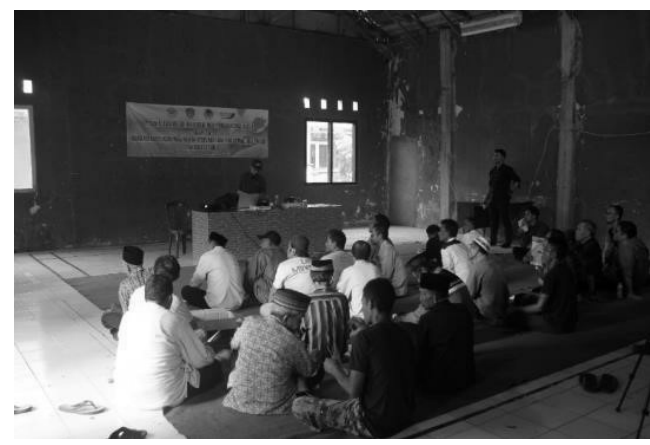

Gambar 1. Suasana penyuluhan di masyarakat Desa Cisalada

Secara umum kegiatan materi penyuluhan berjalan dengan lancar dan peserta terlihat antusias dalam mengikuti penyuluhan tersebut Peserta yang hadir terutama kepala rumah tangga menunjukan ketertarikan dalam praktek penjernihan air. Hal ini disebabkan karena kebutuhan akan air bersih bagi kehidupan rumah tangga sehari-hari. Berdasarkan hasil pengamatan menunjukkan air 
DIFUSI

Volume 2, No.2 Juli 2019

sungai yang berada di tempat pengamatan tergolong air yang hanya aman untuk pertanian dan perkebunan saja, tidak untuk konsumsi rumah tangga. Dengan pengalaman praktek penjernihan air yang diperoleh, masyarakat terinspirasi untuk membuat instalasi penjernihan air skala rumah tangga. Menurut Wahyuningsih dan Pratama (2018) kegiatan pemberdayaan dalam program peduli lingkungan mampu meningkatkan kesadaran masyarakat tentang pentingnya pola hidup bersih dan sehat, meningkatkan pengetahuan masyarakat dalam mengelola sampah serta menimbulkan kesadaran masyarakat tentang kebersihan dan kesehatan lingkungan. Menurut Jefferson, Ciro, dan María (2016) sungai yang melewati pemukiman penduduk pada umumnya telah tercemar oleh limbah rumah tangga, untuk itu pemberdayaan masyarakat dalam pengelolaan sampah di lingkungan pemukiman padat merupakan suatu upaya yang dapat mengurangi tingkat pencemaran sungai.

\section{Penyuluhan kepada siswa se- kolah.}

Penyuluhan kepada siswa sekolah, dilakukan di Madrasah Aliyah Kartaraharja desa Cisalada. Kegiatan dilakukan dari pukul 08.00 WIB. Jumlah siswa yang mengikuti kegiatan ini berjumlah 103 guru dan siswa Peserta dari siswa sekolah ini terlihat aktif dan mudah memahami materi yang disampaikan oleh pemateri. Jika dibandingkan dengan peserta lainnya yaitu masyarakat umum dan karyawan, siswa/siswi sekolah ini terlihat lebih mudah memahami materi. Hal ini dikarenakan materi-materi penyuluhan merupakan bagian dari pelajaran yang diterima dalam proses belajar mengajar di sekolah.

Sebelum kegiatan dilaksanakan maka dilakukan persiapan-persiapan sebagai berikut:

a. Melakukan persiapan alat dan bahan untuk kegiatan penyuluhan.

b. Melakukan uji coba peralatan, seperti alat penjernih air, biomonitoring, penggunaan $\mathrm{pH}$, dan penggunaan termometer.

c. Menentukan waktu pelaksanaan dan lamanya kegiatan pengabdian bersama-sama tim pelaksana.

d. Menentukan dan mempersiapkan materi yang akan disampaikan dalam kegiatan pengabdian masyarakat.

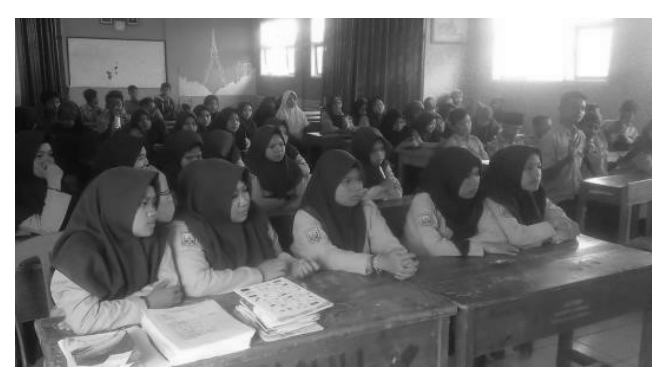

Gambar 2. Penyuluhan Kepada Pelajar MA Kartaharja Cisalada

Peserta kegiatan penyuluhan ini adalah guru dan siswa Madrasah Aliyah (MA) dengan jumlah sebanyak 103 orang peserta. Kegiatan berupa penyampaian materi mengenai DAS dan praktek langsung pembuatan penjernihan air, mengukur $\mathrm{pH}$ air, dan mengukur suhu. Siswa diberi kesempatan melakukan praktek langsung setelah diberikan penjelasan oleh tim penyuluh. Siswa sangat antusias tentang bagaimana pentingnya menjaga dan melestarikan lingkungan 
DIFUSI

Volume 2, No.2 Juli 2019

terutama buang sampah sembarangan, sehingga sungai akan tetap terjaga.

Siswa melakukan praktek langsung secara berkelompok penjernihan air sehingga mereka memahami teknik dan bahan yang digunakan dalam penjernih air. Bahan yang digunakan sederhana sehingga dapat dilakukan atau dipraktekkan di sekolah, dan dikaitkan dengan mata pelajaran.

Selanjutnya siswa melakukan pengamatan hewan guna mendeteksi kualitas air sungai dengan cara mencocokan pada leaflet penentuan kualitas air secara biologi (biomonitoring). Hewan-hewan yang digunakan sebagai parameter kualitas air sangat beranekaragam seperti udang, nimfa lalat, ikan, nimfa capung, jenis molusca, kepik, ungkangungkang dan hewan lainnya. Melalui pengamatan, siswa dapat memahami serta menganalisis kualitas air dengan media hewan sebagai bahan untuk mendeteksi kualitas air sungai.

Kegiatan pengabdian ini memiliki relevansi dengan kebutuhan guru di lapangan. Berdasarkan hasil survey di sekolah, guru-guru biologi masih mengalami kesulitan dalam pembuatan alat penjernih air dan praktek biomonitoring kualitas air sehingga tidak dapat mengajarkan pada siswa. Setelah diadakannya kegiatan penyuluhan, para guru paham tentang proses penjernihan air secara sederhana dan praktek biomonitoring tentang pendeteksian kualitas air sungai

Berdasarkan hasil penyuluhan dan pelatihan yang dilakukan menimbulkan inisiatif pada guru untuk menjadikan materi penyuluhan menjadi bahan pengayaan dan media pembelajaran Biologi. Selain membuat bahan pengayaan pembelajaran Biologi diharapkan guru beserta siswa dapat merancang dan membuat sendiri alat penjernih air secara sederhana, serta dapat mempraktekan cara mendeteksi kualitas air sungai dengan leaflet yang sudah diberikan. Berdasarkan wawancara, tanya jawab dan pengamatan selama kegiatan berlangsung, kegiatan pengabdian pada masyarakat ini khususnya di sekolah memberikan hasil yang positif yaitu meningkatnya pemahaman guru biologi MA Karta Raharja dalam merancang dan membuat bahan serta media pembelajaran biologi serta meningkatnya keterampilan guru dalam pembuatan alat penjernih air dan melakukan pendeteksian kualitas air sungai. Terjadinya peningkatan pemahaman pada guru ini ditunjukkan pada diskusi-diskusi antar tim penyuluh dengan guru yang terjadi selama penyuluhan. Selama diskusi guru mengusulkan bahan-bahan lain yang dapat digunakan untuk penjernihan air.

Selain pada guru manfaat penyuluhan juga terlihat pada siswa yaitu terjadi peningkatan pemahaman siswa tentang pembuatan alat penjernihan air serta cara mendeteksi kualitas air menggunakan parameter hewan yang dijumpai. Peningkatan pemahaman pada siswa ini ditunjukkan dari hasil praktek pembuatan alat penjernihan air dan praktek biomonitoring kualitas air sungai, rata-rata mereka dapat membuat alat penjernihan air secara sederhana serta dapat mendeteksi keberadaan hewan biomonitoring dengan baik dan dapat mnyimpulkan dengan baik kualitas air tempat dilakukannya praktek. Menurut Ardianti, Pratiwi, dan Kanzunnudin (2017) pembe- 
DIFUSI

Volume 2, No.2 Juli 2019

lajaran dengan cara belajar langsung di lapangan dan berbuat sesuatu untuk pelestarian alam efektif dalam membentuk perilaku peduli lingkungan siswa. Menurut Tamara (2016) lingkungan keluarga, sekolah dan masyarakat memberikan peranan yang signifikan dalam menenemkan sikap pedulisiswa terhadap lingkungan.

Beberapa faktor yang mendukung terlaksananya kegiatan pengabdian pada masyarakat khususnya sekolah adalah besarnya minat dan antusiasme para siswa selama kegiatan, sehingga kegiatan berlangsung dengan lancar dan efektif. Sedangkan faktor penghambatnya adalah keterbatasan waktu penyuluhan, sehingga para siswa menyarankan kegiatan penyuluhan harus dilaksanakan dari pagi.

\section{Penyuluhan kepada karyawan perusahaan.}

Kegiatan penyuluhan terhadap karyawan perusahaan dilakukan di perusahaan PT. Berkah Alzico Antalatika Desa Cisalada. Jumlah karyawan yang terlibat dalam kegiatan ini sebanyak 50 orang. Pelaksanaan kegiatan dimulai pada pukul 13.00 dan selesai pada pukul 16.30 WIB.

Proses penyuluhan karyawan terlihat antusias dan menyimak dengan baik materi yang disampaikan. Penyampaian yang sederhana dengan bantuan video serta alat peraga memudahkan pemahaman peserta dari karyawan ini. Materi yang diberikan dalam kegiatan ini terdiri atas tiga yaitu Pelestarian DAS Citarum dengan judul "Menjaga dan Melestarikan Daerah Aliran Sungai
(DAS)", Praktik pendeteksian pencemaran air, dan praktik penjernihan air.

Materi penyuluhan disampaikan secara bergantian oleh penyuluh yang berasal dari mahasiswa Sekolah Pascasarjana Prodi Manajemen Lingkungan, mereka menjelaskan tentang arti penting DAS, kondisi DAS saat ini, dan alasan masyarakat harus menjaga DAS. Selain itu juga dijelaskan juga indikator-indikator yang menunjukkan jika badan air telah mengalami pencemaran. Oleh sebab peserta kegiatan ini adalah karyawan pabrik, kedua pemateri juga mengondisikan agar materi yang disampaikan dapat menggugah pengetahuan karyawan agar memprioritaskan pengelolaan limbah yang baik dan tidak mencemari badan sungai maupun tanah. Dari hasil diskusi, diketahui bahwa limbah yang dibuang oleh perusahaan saat ini masih limbah padat, belum ada limbah cair. Untuk itu, penyuluh menyarankan untuk tetap melakukan pengolahan limbah yang tepat sesuai kategorinya.

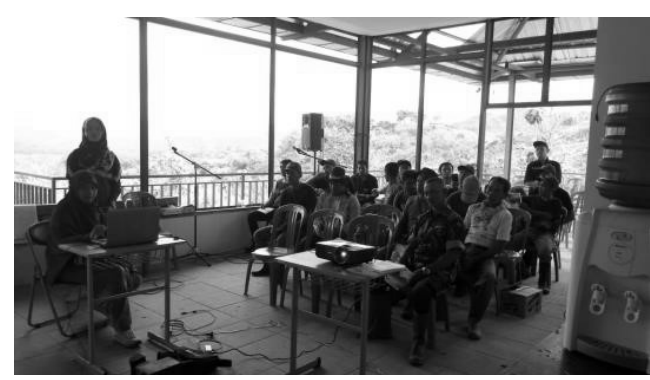

Gambar 3. Pemberian Materi

Pelestarian DAS kepada Karyawan Pabrik

Setelah sesi diskusi dan tanya jawab, peserta diberikan materi praktik tentang pendeteksian pencemaran air dan juga penjernihan.. Sesuai dengan materi yang 
DIFUSI

Volume 2, No.2 Juli 2019

disampaikan sebelumnya, alat yang digunakan untuk pendeteksian pencemaran air adalah kertas $\mathrm{pH}$ dan buku bioindikator. Selain itu, diperkenalkan juga alat pengukuran pencemaran air lainnya yaitu termometer air. Penyuluh kemudian mendemonstrasikan peragaan penggunaan kertas $\mathrm{pH}$ dengan dibantu video peragaan yang ditampilkan melalui proyektor. Pada sesi ini, peserta kegiatan sangat antusias menggunakan kertas $\mathrm{pH}$ dan melihat perubahan dari setiap contoh air yang digunakan. Ada tiga jenis air yang digunakan yaitu air kotor, air basa, dan juga air asam. Ketiga jenis air ini digunakan untuk memberikan gambaran pada karyawan pabrik jika menemukan kondisi air sesuai yang dicontohkan pada saat itu.

Setelah mempraktikan tentang pendeteksian pencemaran air, penyuluh juga mencontohkan praktik penjernihan air. Alat peraga praktik yang digunakan sudah disiapkan sebelumnya oleh panitia. Sebelum sesi ini dimulai, panitia telah melakukan uji coba terhadap alat peraga yang digunakan. Selama proses penyuluhan terjadi diskusi antar karyawan dengan tim penyuluh dan juga dengan perwakilan dari perusahaan. Pihak perusahaan menyatakan pentingnya kegiatan ini bagi karyawan untuk menanamkan kepedulian terhadap lingkungan. Berdasarkan hasil diskusi dengan pihak perusahaan selama ini belum pernah ada penyuluhan-penyuluhan yang berkaitan dengan pelestarian lingkungan bagi karyawan. Untuk itu pihak perusahaan mengharapkan penyuluhan mengenai masalah lingkungan perlu ditindaklanjuti dan dilakukan secara periodik. Diskusi dilanjutkan setelah kegiatan penyuluhan selesai, dari hasil diskusi disepa- kati akan diadakan kerjasama lanjutan dengan perusahaan berkaitan dengan penanaman kepedulian dan pemahaman masalah lingkungan bagi karyawan. Adapun teknik penyuluhan edukasi lingkungan yang akan dilakukan adalah edukasi lingkungan berbasis android agar karyawan tidak terganggu jam bekerjanya dan dapat dilakukan dimana saja dan kapan saja ketika karyawan memiliki waktu luang.

Menurut Yazid dan Alhidayatillah (2017) untuk menjaga kelestarian lingkungan sangat memerlukan partisipasi dari seluruh elemen masyarakat. Partisipasi masyarakat dapat dimulai dari kepedulian masyarakat terhadap informasi-informasi lingkungan baik manfaat dataupun dampak. Berdasarkan informasi yang diperoleh kemudian masyarakat dapat berbuat sesuatu untuk mengurangi permasalahan lingkungan yang ada di daerah masing-masing.

Instrumen sikap peduli lingkungan diberikan kepada karyawan, siswa dan masyarakat sebelum dan setelah kegiatan penyuluhan selesai dilakukan. Peningkatan hasil skor sikap peduli lingkungan warga, siswa dan karyawan disajikan pada gambar 3 dibawah ini.

Berdasarkan hasil penelitian Afrianto (2014) bahwa kegiatan penyuluhan terbukti meningkatkan pengetahuan, sikap dan tindakan masyarakat. Pengetahuan seseorang yang baik dapat menghasilkan perilaku yang baik pula. Tingkat pengetahuan yang baik dapat diberikan melalui metode penyuluhan (Putri dan Menaldi, 2012). Pengetahuan seseorang sangat berhubungan dengan sikap yang dipilihnya sehingga mampu berperilaku 
DIFUSI

Volume 2, No.2 Juli 2019

yang benar. Sikap yang positif terhadap perilaku pro-lingkungan akan mempengaruhi perilaku seseorang menjadi lebih peduli terhadap lingkungan. Hal tersebut menjadi penting dalam rangka mengurangi dampak negatif dari kerusakan lingkungan sehingga tercipta lingkungan yang berkelanjutan (Palupi dan Sawitri, 2015).

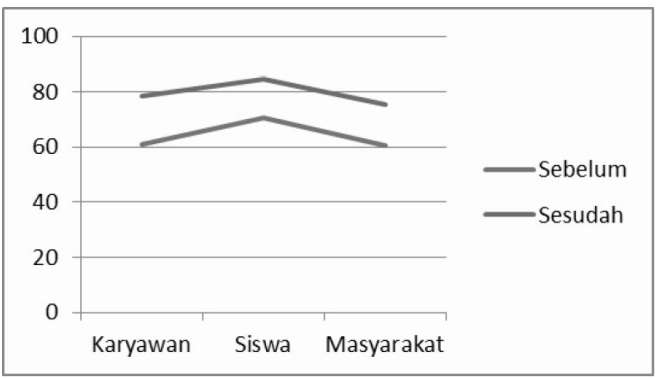

Gambar 4. Persentase Sikap Peduli Lingkungan Karyawan, Siswa, warga.

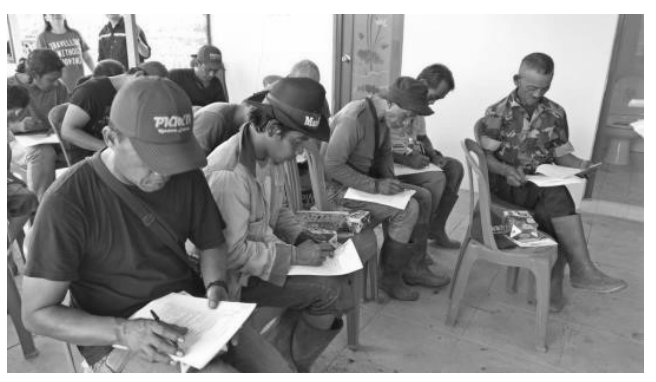

Gambar 5. Penjelasan Mekanisme Pengisian Angket Evaluasi oleh Pemateri

\section{KESIMPULAN}

Kegiatan pengabdian kepada masyarakat tentang pemberdayaan masyarakat terbukti mampu membangkitkan kepedulian lingkungan masyarakat di sekitar DAS Citarum guna untuk menjamin keberlanjutan fungsi DAS Citarum. Ke- giatan ini melibatkan masyarakat, siswa, karyawan dan aparat TNI. Dari hasil angket evaluasi yang diberikan memberikan gambaran bahwa kegiatan ini efektif dalam membangkitkan kepedulian masyarakat disekitar DAS Citarum.

Dari hasil penyuluhan peserta tergerak untuk menindak lanjuti penyuluhan, masyarakat tergerak membuat unit penjernihan air skala rumah tangga untuk memenuhi kebutuhan akan air bersih. Pada guru dan siswa di sekolah, guru berinisiatif materi penyuluhan dijadikan materi pengayaan dalam pembelajaran Biologi. Pengelola perusahaan menginginkan kegiatan edukasi lingkungan ditindaklanjuti dengan kegiatan yang dilakukan secara periodik. Untuk itu kegiatan edukasi lingkungan akan dikembangkan dengan kegiatan edukasi berbasis android agar karyawan tidak terganggu jam kerjanya, dan kegiatan dapat dilakukan kapan saja dan dimana saja ketika karyawan pabrik memiliki waktu luang.

\section{UCAPAN TERIMA KASIH}

Ucapan terima kasih diberikan kepada Sekolah Pascasarjana Universitas Pakuan, LPPM Universitas Pakuan dan PT Berkah Al Zico, Danramil Siliwangi yang telah bekerjasama dalam memberikan motivasi dana sampai kegiatan ini terlaksana dengan baik.

\section{REFERENSI}

[1] Afrianto, D. (2014). Pengaruh Penyuluhan Terhadap Pengetahuan, Sikap dan Tindakan Petani Paprika Di Desa Kumbo-Pasuruan Terkait Penggunaan Alat Pelin- 
dung Diri Dari Bahaya Pestisida. Fakultas Kedokteran dan Ilmu Kesehatan Universitas Islam Negeri (UIN) $1435 \mathrm{H} / 2013 \mathrm{M}$.

[2] Ardianti, S., Pratiwi, I., dan Kanzunnudin, M. (2017). Implementasi Project Based Learning (PjBL). Jurnal Refleksi Edukatika, 7(2), 145-150.

[3] Jefferson, G. M., Ciro, P. M., dan María, M. S. (2016). Environmental education and the Bogotá River: an intervention to be carried out in Cundinamarca intervention to be carried out in Cundinamarca ( Colombia ), 2046(January 2017). https: //doi.org/10.1080/10382046.2016. 1262510

[4] Lawrence, P., dan Meigh, J. (2003). The Water Poverty Index : an International Comparison Keele Economics Research Papers, 2002(October 2002).

[5] Liang, W., dan Yang, M. (2018). Urbanization, Economic Growth and Environmental Pollution: Evidence from China. Sustainable Computing: Informatics and Systems. https://doi.org/10.1016/ j.suscom.2018.11.007

[6] Maulani, N., dan Sumiarsa, D. (2013). Identifikasi Kemiskinan Air Di Daerah Aliran Sungai Citarum Hulu: KASUS DAERAH BANDUNG RAYA, 11(2), 9299.

[7] Mikro, D. A. S., Dan, K., Awang, S. A., Faida, L. R. W., dan Maryudi, A. (2016). Pemberdaya an masyarakat dalam pengelolaan das mikro: konsep dan implementtasi, 7(2), 175-187.

[8] Palupi, T., dan Sawitri, D. R. (2015). Hubungan Antara Sikap Dengan Perilaku Pro-Lingkungan Ditinjau dari Perspektif Theory Of Planned Behavior Relationship Between Attitude And Pro-Environmental Behavior from the Perspective of Theory of Planned Behavior Perilaku Pro-Lingkungan, 14, 2015-2018.

[9] Putri, I. R., dan Menaldi, S. L. (2012). Efektivitas Penyuluhan Terhadap Peningkatan Pengetahuan Santri Mengenai Penularan Pedikulosis di Pesantren X, Jakarta Timur, 61.

[10] Tamara, R. M. (2016). Peranan Lingkungan Sosial Terhadap Pembentukan Kabipaten Cianjur, 16(April), 44-55.

[11] Wahyuningsih, I., dan Pratama, M. R. (2018). Pemberdayaan Masyarakat Bausasran Yogyakarta dalam Program Peduli Lingkungan, Kebersihan dan Kesehatan, 2(1), 135-142.

[12] Wihardjo, S. D., Hartati, S., Nurani, Y., dan Sujarwanta, A. 2017). The effects of green schooling knowledge level and intensity of parental guidance on the environmental awareness of the early age student, 12(5), 251257. https://doi.org/10.5897/ ERR2015.2608

[13] Yazid, Y., dan Alhidayatillah, N. (2017). Partisipasi masyarakat dalam pemberdayaan lingkungan, 28(1), 1-9. 